\title{
Coral diseases near Lee Stocking Island, Bahamas: patterns and potential drivers
}

\author{
Joshua D. Voss*, Laurie L. Richardson \\ Department of Biological Sciences, Florida International University, Miami, Florida 33199, USA
}

\begin{abstract}
The number of coral diseases, coral species they infect, number of reported cases, and range over which these diseases are distributed have all increased dramatically in the past 3 decades, posing a serious threat to coral reef ecosystems worldwide. While some published studies provide data on the distribution of coral diseases at local and regional levels, few studies have addressed the factors that may drive these distributions. We recorded coral disease occurrence, prevalence, and severity along with temperature, sedimentation, and coral population data (species abundance and colony size) over 2 consecutive summers on reefs near Lee Stocking Island (LSI) in the Bahamas' Exuma Chain. In 2002 a total of 11092 coral colonies (all species present) were examined within a survey area of $9420 \mathrm{~m}^{2}$, and 13973 colonies within $10362 \mathrm{~m}^{2}$ in 2003. Similar to other reports, relatively large, framework species including Siderastrea siderea, Colpophyllia natans, and Montastraea annularis, along with the smaller Dichocoenia stokesi, were the species most susceptible to coral disease. Recurring infections were observed on individual colonies from 2002 to 2003, and were more likely for black band disease (BBD) than for either white plague (WP) or dark spots syndrome (DS). In 2002, WP and DS demonstrated clumped distributions, while BBD was randomly distributed. However, in 2003 BBD and WP were clumped. This is the first study, to our knowledge, that quantitatively documents coral disease dynamics on reefs surrounding LSI.
\end{abstract}

KEY WORDS: Coral reefs $\cdot$ Coral disease $\cdot$ Black band disease $\cdot$ White plague $\cdot$ Dark spots syndrome Resale or republication not permitted without written consent of the publisher

\section{INTRODUCTION}

Over the past 3 decades both the number of coral diseases and their contribution to the degradation of coral reef ecosystems have increased dramatically (Goreau et al. 1998, Richardson 1998, Harvell et al. 1999, Porter et al. 2001, Rosenberg \& Loya 2004). In addition to increases in the number of diseases and syndromes reported, the number of reported cases and species affected has also risen (Porter et al. 1999, Green \& Bruckner 2000, Porter et al. 2001, Weil 2004). During this same period the geographical range of coral diseases has expanded from initial observations in the greater Caribbean (Antonius 1973, Dustan 1977, Gladfelter et al. 1977) to a worldwide distribution (Green \& Bruckner 2000, Sutherland et al. 2004). Knowledge of the causes and resulting distributions of coral diseases is fundamental for the determination of their potential impact on coral communities. In this study we report the occurrence, prevalence, and distribution of coral diseases in the Bahamas' Exuma Cays near Lee Stocking Island (LSI). Furthermore, we discuss the roles of 3 potential factors influencing coral diseases in this region: (1) temperature, (2) sedimentation, and (3) coral colony size.

Lee Stocking Island is relatively pristine, with little local environmental stress from, for example, sewage discharge, pesticide pollution, or river runoff (Dennis \& Wiklund 1993). The area is geographically isolated from human population centers, the nearest being Georgetown, Great Exuma (pop. 1100) approximately $45 \mathrm{~km}$ to the southeast. This region receives little commercial or sport fishing, and a voluntary notake zone surrounds LSI. These factors make it an ideal region to study coral diseases with negligible human influence.

To date little is known about environmental factors or conditions that promote pathogenic infections of 
corals. While previous and ongoing studies, including this one, provide data on the distribution and abundance of diseases, few studies have addressed the factors that may drive these distributions. Global climate change (including increased sea surface temperature) and increased sedimentation have been suggested, among other factors, as potential causes of the increase in coral disease incidence (Harvell et al. 1999, Green \& Bruckner 2000, Rosenberg \& Ben-Haim 2002). In addition to environmentally induced coral bleaching (Brown 1997, Fitt et al. 2001), black band disease (BBD) (Edmunds 1991, Kuta \& Richardson 1996, Bruckner et al. 1997), white plague (WP) (Richardson et al. 1998), aspergillosis (Alker et al. 2001), bacterial bleaching (Rosenberg \& Ben-Haim 2002), and dark spots syndrome (DS) (Gil-Agudelo \& Garzon-Ferreira 2001) have been associated with relatively higher water temperature. One quantitative study (Kaczmarsky et al. 2005) has shown a correlation between BBD and proximity to sewage outflow.

Coral colony size may also potentially influence the occurrence and severity of coral diseases. Water-borne pathogens, or other infectious vectors, have an increased probability of coming into contact with colonies of greater surface area. Larger colonies are also likely to be older than their smaller neighbors, and may have higher accumulated exposure to pathogens over time. This relationship may transcend a simple correlation with surface area. For example, it has been hypothesized that smaller coral colonies may allocate more resources toward defense mechanisms rather than reproduction due to an increased threat of total mortality (Kim \& Havell 2002). It is also possible that relatively larger colonies achieve their size through natural resistance to disease.

\section{MATERIALS AND METHODS}

Surveys. We quantitatively surveyed the same 10 reef sites at LSI in June to July of both 2002 and 2003 (Fig. 1). Five of these reefs were located at 8 to $20 \mathrm{~m}$ depths on the northern side of the Exuma Chain, facing the Exuma Sound. The other 5 were located in shallower (2 to $8 \mathrm{~m}$ ) more protected areas. Three haphazardly located surveys were conducted at each reef, totaling $9420 \mathrm{~m}^{2}$ in 30 surveys during 2002, and $10362 \mathrm{~m}^{2}$ in 33 surveys in 2003. In 2003, 1 additional survey was conducted at Horseshoe, North Perry, and South Perry for a total of 4 surveys on these 3 reefs. The surveys were conducted within circular sites $(20 \mathrm{~m}$ diameter) using five $2 \mathrm{~m}$ wide concentric radial transects following the method of Edmunds (1991). Within each survey every scleractinian coral colony was identified to species and measured (maximum diameter) to

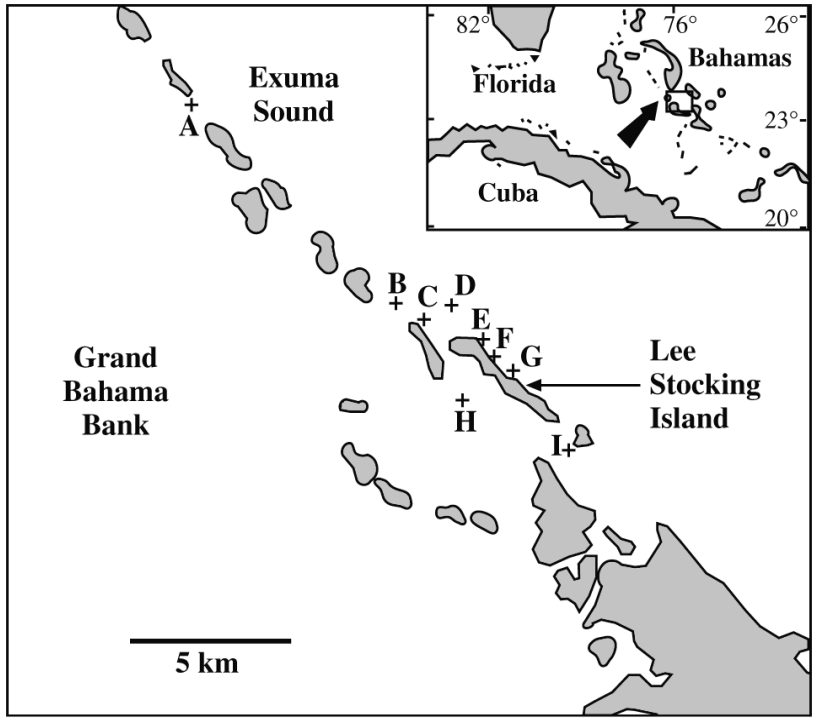

Fig. 1. Locations of study reefs near Lee Stocking Island (LSI), Bahamas. At each reef site, represented by labeled crosses, 3 to 4 surveys were conducted. A: Goby Spot, B: Rainbow Gardens, C: North Norman's, D: White Horse, E: North Perry, F: South Perry, G: Horseshoe and Horseshoe Shallow, H: Tug and Barge, I: Square Rock. Note that 2 of the study reefs (Horseshoe and Horseshoe Shallow) are depicted as ' $G$ '

the nearest $5 \mathrm{~cm}$. Infected colonies were tagged and disease type and severity (estimated percent tissue loss by class: $1-10 \%, 11-20 \%$, etc. to $91-100 \%$ ) were recorded. The presence of disease was designated as disease occurrence, since it was unknown if a diseased colony represented a new case of disease in the population (defined as incidence). Disease prevalence was calculated as the proportion of infected colonies (percentage) both for all species and individually for susceptible species. Disease recurrence from 2002 to 2003 was assessed by examining previously diseased and tagged colonies. It is not know whether recurrence was due to a new infection or reemergence of the same infection.

Sediment and temperature data. PVC pipe sediment traps $(5 \times 30 \mathrm{~cm})$ secured to a steel stake at the center of each survey site were used to collect sediments over 4 consecutive $1 \mathrm{wk}$ intervals (with accumulated sediments collected at the end of each week) from June 22 to July 20, 2002. Sediment samples were dried at $60^{\circ} \mathrm{C}$ until constant weights were recorded. Temperature was recorded using Stowaway TidbiT ${ }^{\circledR}$ temperature loggers (resolution $=0.1^{\circ} \mathrm{C}$, calibrated by the manufacturer) placed at Horseshoe $(8 \mathrm{~m})$ and North Perry (22 m) reefs (Fig. 1).

Statistical analyses. Mean disease prevalence values for pooled species in each year were arcsine transformed for normality and compared using a Stu- 
dent's $t$-test. Distributions of BBD, WP, and DS were tested against the Poisson distribution using the goodness-of-fit $G$-test (with 5 levels: 0, 1, 2, 3, 4 or more infections per site) to determine if diseases were clumped or randomly distributed. Within each species the mean size of infected individuals was compared to the mean size of healthy, non-infected individuals using the nonparametric Mann-Whitney $U$-test. For BBD and WP, coral species were pooled and colony size was tested for correlation with disease severity class (categorical) using Spearman rank correlation analysis. Only 2 cases of DS with quantifiable tissue degradation were observed. Therefore this disease was omitted from the severity-size regression analysis. Sedimentation rates were compared using the Mann-Whitney $U$-test. All statistical procedures were conducted using SAS 9.0.

\section{RESULTS}

The overall occurrence, prevalence, and recurrence of coral diseases on reefs near LSI in 2002 and 2003 are given in Table 1. This table presents overall values within the total coral population, with $\mathrm{n}=11092$ colonies in 2002 and 13973 colonies in 2003 examined. From 2002 to 2003 we observed an increase in BBD prevalence, a decrease in DS prevalence, and no change in WP prevalence. There was no significant change over the 2 yr period when considering all 3 diseases together. Within-colony disease recurrence between 2002 and 2003 was recorded in $76 \%$ of colonies infected with BBD and in $29 \%$ of colonies infected with DS. WP infections did not recur.

BBD was observed on 3 coral species in 2002 (Colpophyllia natans, Siderastrea siderea, and Montastraea annularis) and 4 species in 2003 (also Diploria strigosa). While the greatest number of infections (15 of 1335 colonies in 2002, 35 of 1924 colonies in 2003) was found on $S$. siderea (Table 2), these values were $<2 \%$

Table 1. Occurrence, prevalence, and recurrence (percentage of colonies previously infected in brackets) of coral diseases for all coral species observed near LSI in 2002 (area surveyed $=9425 \mathrm{~m}^{2}, \mathrm{n}=11092$ coral colonies) and 2003 (area surveyed $=10362 \mathrm{~m}^{2}, \mathrm{n}=13973$ colonies). Asterisks indicate significant differences ( $t$-test with arcsine transformed values) in mean prevalence values between years $(\alpha=0.05)$

\begin{tabular}{|c|c|c|c|c|c|}
\hline \multirow[t]{2}{*}{ Disease } & \multicolumn{2}{|c|}{2002} & \multirow{2}{*}{$\begin{array}{l}\text { Occur- } \\
\text { rence }\end{array}$} & \multirow{2}{*}{$\begin{array}{c}2003- \\
\text { Preva- } \\
\text { lence }(\%)\end{array}$} & \multirow[b]{2}{*}{$\begin{array}{l}\text { Recur- } \\
\text { rence }\end{array}$} \\
\hline & $\begin{array}{l}\text { Occur- } \\
\text { rence }\end{array}$ & $\begin{array}{c}\text { Preva- } \\
\text { lence (\%) }\end{array}$ & & & \\
\hline Black band (BBD) & 17 & $0.15^{*}$ & 44 & $0.31^{*}$ & $13(76)$ \\
\hline White plague (WP) & 18 & 0.16 & 24 & 0.17 & 0 \\
\hline Dark spots (DS) & 38 & $0.34^{*}$ & 17 & $0.12^{*}$ & $11(29)$ \\
\hline All diseases & 73 & 0.66 & 85 & 0.61 & $24(33)$ \\
\hline
\end{tabular}

of the $S$. siderea population. The $C$. natans population showed the greatest percentage of infected colonies (1.4\% in 2002, and $7.6 \%$ in 2003, Table 2, Fig. 2A). For both species, disease prevalence increased from 2002 to 2003 (Fig. 2A). BBD was present at extremely low values amongst $D$. strigosa and $M$. annularis (prevalence $<0.15 \%$ for each species). WP was observed on 4 species in both 2002 and 2003. For 2002 and 2003 there were, respectively, 10 and 13 infected colonies of 374 and 477 total number of colonies of Dichocoenia stokesi; 2 and 1 infected colonies of 793 and 802 total Montastraea cavernosa; 3 and 6 infected colonies of 1685 and 1787 total $M$. annularis; and 3 and 4 infected colonies of 1335 and 1924 total S. siderea (Table 2). WP was most prevalent among the $D$. stokesi population (Fig. 2B), exhibiting prevalence values of $2.7 \%$ for both years.

The species Siderastrea siderea was most susceptible to coral diseases in general, with colonies exhibiting signs of DS as well as both WP and BBD (Table 2). This is the only species that was observed to be infected with DS (38 of 1335 colonies in 2002, and 17 of 1924 colonies in 2003, with prevalence values of 2.8 and $0.88 \%$, respectively). When summing all 3 diseases, $S$. siderea exhibited an overall disease prevalence of 4.2 and $2.9 \%$ in 2002 and 2003 respectively.

Coral colony abundances (summed) for the 6 species observed to be infected with disease was 4811 in 2002 and 5799 in 2003 (Table 2). The total reef areas surveyed each year varied, with 30 sites - or $9420 \mathrm{~m}^{2}$ in 2002 and 33 sites - or $10362 \mathrm{~m}^{2}$ - in 2003. The overall density of susceptible colonies was 160 per site in 2002 and 176 in 2003. While the overall abundance of the locally susceptible species (6 of 31 species present) represented $43 \%$ percent of total colonies in 2002 and $42 \%$ in 2003, observed disease prevalence was only $1.5 \%$ of the susceptible populations in both 2002 and 2003. The observed disease prevalence for the entire coral population (susceptible and nonsusceptible species) was $0.66 \%$ in 2002 and $0.61 \%$ in 2003. (Table 1).

The pattern of disease distribution in terms of disease occurrence per reef varied per disease (Table 3). In 2002, $G$-tests of observed site frequencies against those predicted by the Poisson distribution indicated a clumped distribution for WP $(G=10.51 \mathrm{df}=4$, p < 0.05 ) and DS ( $G=12.47$, df $=4, \mathrm{p}<$ 0.05). The distribution of BBD was not significantly different from the Poisson distribution ( $G=1.69$, $\mathrm{df}=4, \mathrm{p}>0.05)$. However in 2003 disease distributions shifted. Both BBD $(G=20.52$, df $=4$, p 
Table 2. Disease occurrence (no. of observed colonies with each disease), prevalence (in brackets, \%), and abundance of diseased corals near LSI in 2002 and 2003. Abbreviations as in Table 1

\begin{tabular}{|c|c|c|c|c|c|c|c|c|}
\hline \multirow{2}{*}{$\begin{array}{l}\text { Coral } \\
\text { species }\end{array}$} & \multicolumn{4}{|c|}{-2002} & \multirow[b]{2}{*}{$\begin{array}{l}\text { No. of } \\
\text { colonies }\end{array}$} & \multirow{2}{*}{$\overline{\mathrm{BBD}}^{2}$} & \multirow[b]{2}{*}{ WP } & \multirow[b]{2}{*}{ DS } \\
\hline & $\begin{array}{l}\text { No. of } \\
\text { colonies }\end{array}$ & BBD & WP & DS & & & & \\
\hline Colpophyllia natans & 71 & $\begin{array}{c}1 \\
(1.4)\end{array}$ & 0 & 0 & 79 & $\begin{array}{c}6 \\
(7.6)\end{array}$ & 0 & 0 \\
\hline Dichocoenia stokesi & 374 & 0 & $\begin{array}{c}10 \\
(2.7)\end{array}$ & 0 & 477 & 0 & $\begin{array}{c}13 \\
(2.7)\end{array}$ & 0 \\
\hline Diploria strigosa & 553 & 0 & 0 & 0 & 730 & $\begin{array}{c}1 \\
(0.14)\end{array}$ & 0 & 0 \\
\hline Montastraea cavernosa & 793 & 0 & $\begin{array}{c}2 \\
(0.25)\end{array}$ & 0 & 802 & 0 & $\begin{array}{c}1 \\
(0.12)\end{array}$ & 0 \\
\hline Montastraea annularis & 1685 & $\begin{array}{c}1 \\
(0.06)\end{array}$ & $\begin{array}{c}3 \\
(0.18)\end{array}$ & 0 & 1787 & $\begin{array}{c}2 \\
(0.11)\end{array}$ & $\begin{array}{c}6 \\
(0.33)\end{array}$ & 0 \\
\hline Siderastrea siderea & 1335 & $\begin{array}{c}15 \\
(1.1)\end{array}$ & $\begin{array}{c}3 \\
(0.2)\end{array}$ & $\begin{array}{c}38 \\
(2.8)\end{array}$ & 1924 & $\begin{array}{c}35 \\
(1.8)\end{array}$ & $\begin{array}{c}4 \\
(0.20)\end{array}$ & $\begin{array}{c}17 \\
(0.88)\end{array}$ \\
\hline Totals & 4811 & $\begin{array}{c}17 \\
(0.35)\end{array}$ & $\begin{array}{c}18 \\
(0.37)\end{array}$ & $\begin{array}{c}38 \\
(0.79)\end{array}$ & 5799 & $\begin{array}{c}44 \\
(0.76)\end{array}$ & $\begin{array}{c}24 \\
(0.41)\end{array}$ & $\begin{array}{c}17 \\
(0.29)\end{array}$ \\
\hline $\begin{array}{l}\text { Total diseases (all } 6 \text { coral } \\
\text { species) }\end{array}$ & & & $\begin{array}{c}73 \\
(1.5)\end{array}$ & & & & $\begin{array}{c}85 \\
(1.5)\end{array}$ & \\
\hline
\end{tabular}
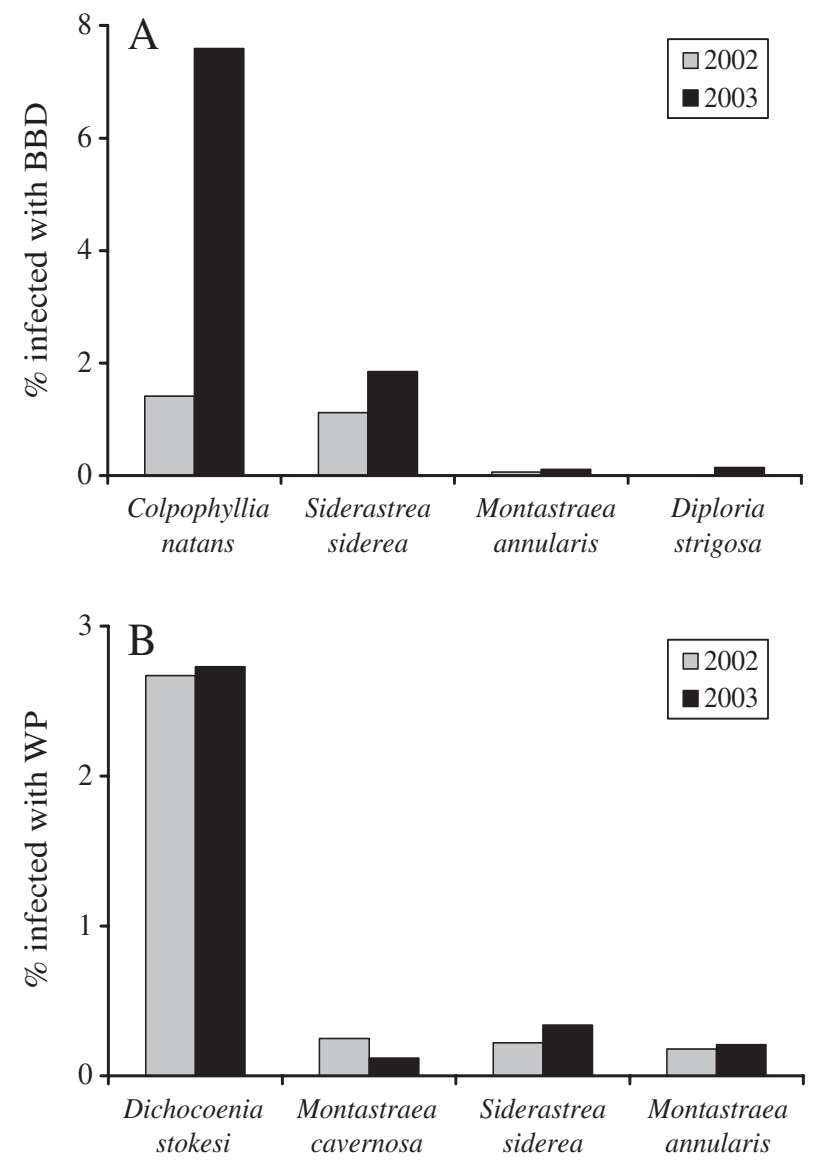

Fig. 2. Percent of colonies infected with (A) black band disease (BBD) and (B) white plague (WP) in 2002 and 2003. Note different coral species and scales for each graph
$<0.001)$ and WP $(G=16.20, \mathrm{df}=4, \mathrm{p}<0.01)$ exhibited clumped distributions while DS was randomly distributed ( $G=1.20$, $\mathrm{df}=4$, p > 0.05).

Spearman rank correlation analyses indicated that disease severity ( $\%$ of tissue lost) was negatively correlated with colony size for both BBD $\left(\rho^{2}=0.34, p<0.01\right)$ and WP $\left(\rho^{2}=0.47, p<0.01\right.$, Fig. 3$)$. In all but 2 cases tissue loss was not observed with DS. Therefore severity measures were not recorded.

Within populations of individual coral species, infected colonies did not differ in size from healthy individuals ( $p>0.05$ for all species, data not shown). However, when comparing different coral species there was a distinctive general trend in which the relatively larger species were observed to be susceptible to disease (Fig. 4). Only one relatively smaller species, Dichocoenia stokesi, was observed with disease (WP).

During the survey period in 2003 water temperatures on the outer reefs dropped from $28^{\circ} \mathrm{C}$ to below $27.5^{\circ} \mathrm{C}$ from June 4 to June 14 as a result of a weak cold front (Fig. 5). During this period BBD infections became visually undetectable and coral tissue loss ceased on all Colpophyllia natans colonies that had been infected $(n=6)$. Similar cessation of disease signs occurred in 7 out of 35 BBD infected Siderastrea siderea colonies. As temperatures increased after June 14, BBD infections began to reappear on the previously infected colonies. All colonies aside from one $S$. siderea colony exhibited $\mathrm{BBD}$ in the same areas that had been previously infected on each colony. The BBD-free colony did not exhibit signs of BBD for the remainder of our study. 
Table 3. Number of diseased colonies (all species) observed at each reef (pooled survey sites) near LSI in 2002 and 2003. Clumped distributions were present for WP and DS in 2002 ( $p<0.05)$ and BBD and WP in $2003(p<0.01)$. BBD was random in 2002 and DS was random in 2003. (See text for statistics.)

\begin{tabular}{|c|c|c|c|c|c|c|c|}
\hline \multirow[t]{2}{*}{ Site } & \multirow{2}{*}{ Map icon } & \multicolumn{3}{|c|}{-2002} & \multicolumn{3}{|c|}{-2003} \\
\hline & & BBD & WP & DS & BBD & WP & DS \\
\hline Goby Spot & A & 2 & 4 & 1 & 1 & 8 & 1 \\
\hline Rainbow Gardens & B & 1 & 0 & 6 & 3 & 0 & 4 \\
\hline North Norman's & $\mathrm{C}$ & 1 & 0 & 6 & 2 & 3 & 2 \\
\hline White Horse & $\mathrm{D}$ & 3 & 3 & 7 & 4 & 4 & 3 \\
\hline North Perry & E & 2 & 4 & 5 & 6 & 0 & 2 \\
\hline South Perry & $\mathrm{F}$ & 1 & 4 & 8 & 5 & 1 & 2 \\
\hline Horseshoe & G & 4 & 2 & 3 & 14 & 6 & 1 \\
\hline Horseshoe Shallow & G & 2 & 0 & 2 & 9 & 0 & 1 \\
\hline Tug and Barge & $\mathrm{H}$ & 0 & 0 & 0 & 0 & 2 & 0 \\
\hline Square Rock & I & 1 & 1 & 0 & 0 & 0 & 1 \\
\hline
\end{tabular}

Sedimentation rates recorded in 2002 were significantly higher (Mann-Whitney $U=109$, p < 0.05) on sites in which BBD was observed $(\mathrm{n}=21$, median $=$ $0.13 \mathrm{~g} \mathrm{~cm}^{-2} \mathrm{wk}^{-1}$ ) than on sites with no signs of disease ( $\mathrm{n}=9$, median $=0.06 \mathrm{~g} \mathrm{~cm}^{-2} \mathrm{wk}^{-1}$ ).
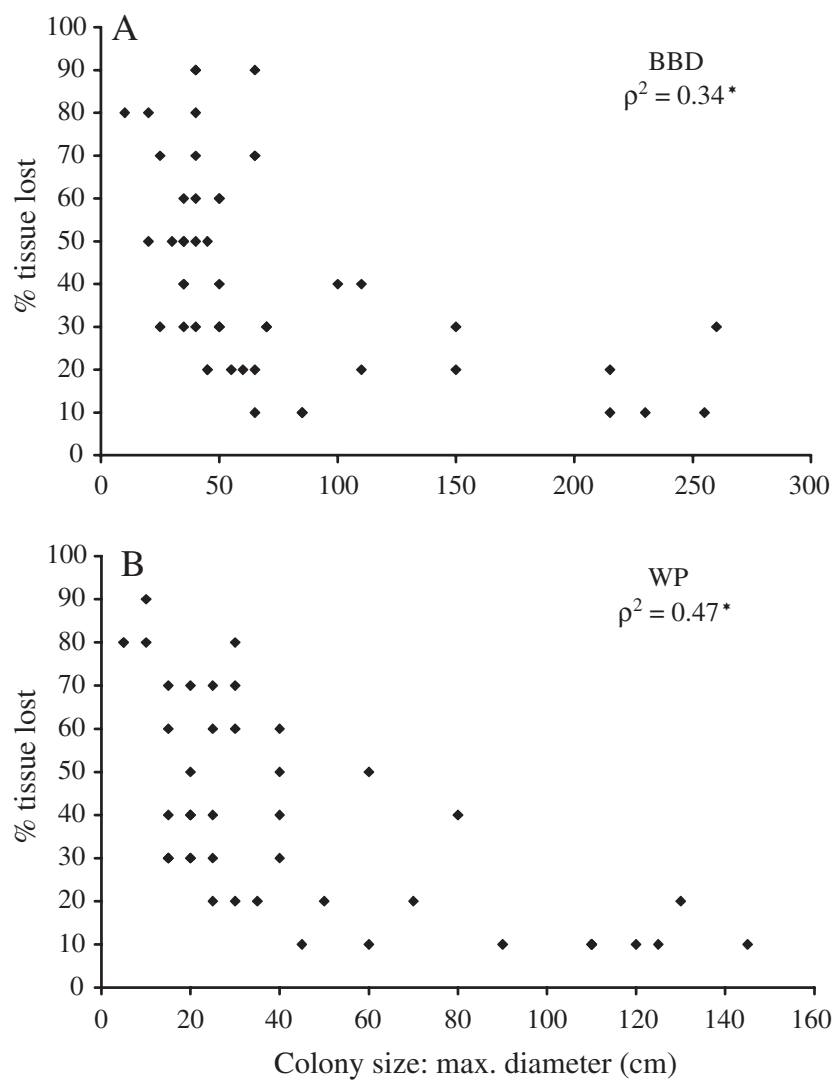

Fig. 3. Colony size (maximum diameter, $\mathrm{cm}$ ) vs. severity (percent tissue loss) for (A) black band disease and (B) white plague. Spearman Rank correlation analysis; asterisk indicates $\mathrm{p}<0.01$. Note different scales for each graph

\section{DISCUSSION}

To our knowledge only one study (Weil et al. 2002) has been conducted in the Caribbean that reports disease prevalence for all scleractinian coral species. The overall (total) disease prevalence values we report for LSI are low compared to the prevalence values observed by Weil et al. (2002). While we recorded total disease prevalence values of 0.66 and $0.61 \%$ in 2002 and 2003, respectively (Table 1), Weil et al. (2002) observed prevalence values ranging from 0.07 to $9.78 \%$ throughout the Caribbean, with a mean total disease prevalence of $3.02 \%$.

Overall BBD prevalence values near LSI were similar to those reported in most previous BBD surveys, which are generally less than 1\% (Edmunds 1991, Kuta \& Richardson 1996, Weil et al. 2002). In contrast, Bruckner et al. (1997) observed BBD prevalence of over $7 \%$ in an outbreak on reefs of Jamaica. The approximate doubling in BBD prevalence near LSI from 2002 to 2003 warrants continued monitoring to document whether BBD occurrence is progressing to an outbreak, i.e. a large number of cases of disease in a short period of time, in this region.

The recurrence of $\mathrm{BBD}$ infections on individual colonies suggests that bacteria associated with the infection may remain on or near the colony in a nonpathogenic state during the colder months of the year. BBD reservoirs have been observed as non-pathogenic biofilms in sediment pockets on apparently healthy coral colonies of BBD susceptible species (Richardson 1997). On reefs of the Florida Keys, individual corals with BBD often exhibit BBD signs at the same site on the colony during the warm summer months of each year (authors' pers. obs.).

The WP prevalence values we report did not differ from 2002 to 2003 and are comparable to Weil et al. (2002), who observed prevalence values ranging from 0 to $3.7 \%$ (mean $=0.77 \%$ ). During outbreaks of $\mathrm{WP}$, prevalence has been reported as high as $33 \%$ among susceptible species (Richardson et al. 1998). The lack of observed recurrence of WP may be related to its rapid progression, up to $2 \mathrm{~cm} \mathrm{~d}^{-1}$, across colonies (Richardson et al. 1998), which often results in the complete mortality of the infected colony. In this study, 6 of the white plague infected colonies at LSI were completely denuded by the end of July, 2002.

While we measured DS prevalence values of 0.34 and $0.12 \%$ in 2002 and 2003 (Table 1), Gil-Agudelo \& Garzon-Ferreira (2001) and Garzon-Ferreira \& Gil 


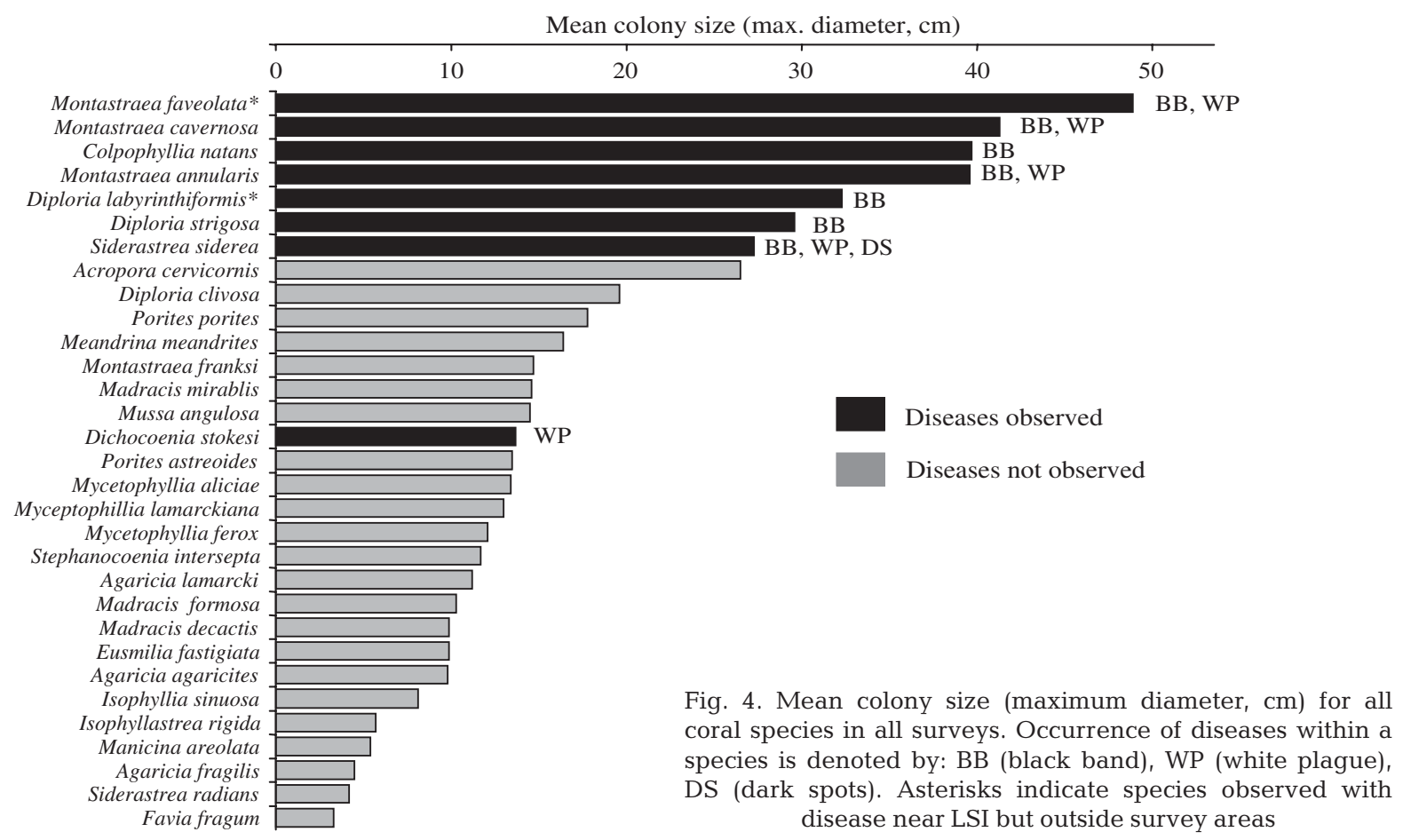

(1998) reported prevalence values of $16.45 \%$ and $2.85 \%$ on reefs off the Columbian coast and 4 southwestern Caribbean atolls, respectively. Additionally, the DS infections we observed were found exclusively on Siderastrea siderea. Of the 1545 DS-infected colonies observed on Colombian coastal reefs, $62.9 \%$ were Montastraea annularis and $31.2 \%$ were $S$. siderea, the remainder being other Montastraea spp. and Stephanocoenia intercepta (Gil-Agudelo \& Garzon-Ferreira 2001). Thus far no pathogen has been identified for DS. Tissue loss has been documented at rates of $3.99 \mathrm{~cm} \mathrm{mo}^{-1}$ (Cervino et al. 2001).

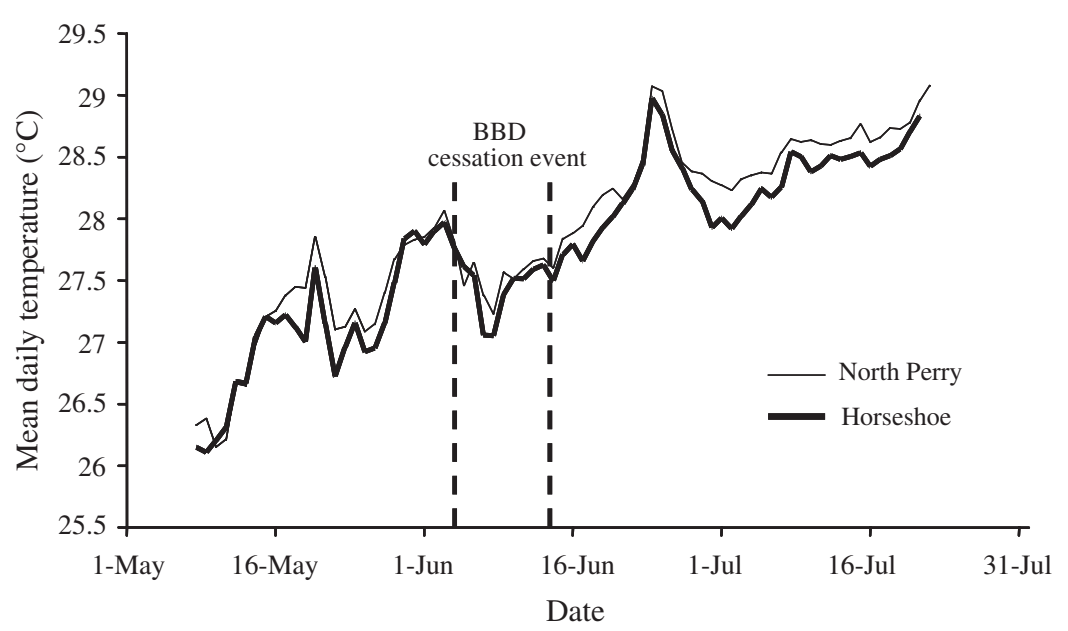

Fig. 5. Mean daily temperature $\left({ }^{\circ} \mathrm{C}\right)$ for 2 outer reefs near LSI and associated black band disease cessation event in 2003. BBD monitoring began on June 1
We found that disease distributions were variable in time. While WP and DS demonstrated clumped distributions in 2002, WP and BBD were clumped in 2003. Clumped distributions are consistent with an infectious model of disease transmission. Previous studies have shown clumped distributions for both WP (Richardson et al. 1998, Borger 2003) and DS (Gil-Agudelo \& Garzón-Ferreira 2001). One study of WP reported that disease distribution was neither clumped nor density dependent (Nugues 2002). BBD has been observed in clumped distributions in numerous studies (Edmunds 1991, Kuta \& Richardson 1996, Bruckner \& Brucker 1997, Borger 2003). At this time, the mechanisms of disease transmission and infection are not known for any of these diseases.

It has been proposed that increased sea water temperature associated with global warming is a direct and important factor in the overall increase in coral disease incidence (Rosenberg \& Ben-Haim 2002). Several studies have shown that the pathogens for gorgonian aspergillosis (Alker et al. 2001), bacterial bleaching (Banin et al. 2001), WP (Remily 2004), and a cyanobacterial member of the BBD consortium (Richardson \& Kuta 2003) grow optimally at or above $30^{\circ} \mathrm{C}$. In addition, Fitt et al. (2001) demonstrated that corals become physiologically stressed above $30^{\circ} \mathrm{C}$, po- 
tentially causing an increased susceptibility to infections. Such data may explain, at least in part, why coral diseases are generally most active during warmer months of the year.

Our observation of BBD cessation on corals when temperatures dropped below $27.5^{\circ} \mathrm{C}$, and its subsequent return as temperatures warmed, suggest that temperature tightly controls disease activity. This observation is in agreement with those of Rützler et al. (1983) who documented BBD activity as being limited to water temperatures at and above $28^{\circ} \mathrm{C}$.

Our observation of increased sedimentation rates at sites with disease as compared to healthy sites indicates that sediments may play a role in coral infections. Sediments are capable of harming corals in myriad processes. Abrasion and/or smothering directly damage coral tissues. Indirect stresses to corals include decreased light availability, reducing photosynthetic rates of zooxanthellae, and increased mucus production, requiring additional energy expenditures by the coral (Riegl \& Branch 1995). Damage and stress to corals may make them more susceptible to infections by microbial pathogens. Furthermore, sediments may act as vectors of coral disease. In addition to its potential role in disease, increased sedimentation has been shown to reduce reproductive success in corals (Gilmour 1999), exacerbating its effect on coral reef health. We stress, however, that our results consist of short-term data and that experimental studies are needed to definitively assess the role of sedimentation in coral diseases.

Although within species there was no statistical difference in the sizes of infected and healthy individuals, we observed coral diseases primarily in those species with larger mean colony sizes, that is, Colpophyllia natans, Diploria strigosa, Montastraea annularis, M. cavernosa, and Siderastrea siderea. This pattern has been reported in other regions for a number of coral diseases including WP (Nugues 2002, Borger 2003), BBD (Borger 2003), DS (Borger 2003), and gorgonian aspergillosis (Kim \& Harvell 2002). An exception appears to be Dichocoenia stokesi, a relatively small coral species which was most susceptible to WP in our study, and was also reported as such by Richardson et al. (1998).

It is important to note that most of the coral species that were not diseased at LSI have been found to be susceptible to diseases in other areas of the Caribbean (Sutherland et al. 2004, Weil 2004). It is unknown whether disease occurrence per species for multi-host coral diseases is correlated with the overall prevalence of disease in the population, or whether the individual susceptibility of coral colonies controls coral disease patterns.

Disease severity (percent of coral tissue lost) was negatively correlated with colony size for both BBD and WP. A similar negative correlation between severity and large size has been observed previously in WP
(Nugues 2002). This may be etiologically significant in that while relatively large, ecologically important species (and colonies) may be at an increased risk of infection, they may also have a greater chance of recovering and surviving. Small colonies, on the other hand, succumb to disease more quickly given constant tissue degradation rates. This could be particularly important for diseases with seasonal patterns of occurrence. While large colonies may not experience total mortality, they can potentially act as reservoirs for coral pathogens and thus promote disease recurrence. Furthermore, due to variation in reproductive capabilities and stress resistance among size classes within a population, partial mortality in large colonies and total mortality in small colonies may have effects beyond quantifiable tissue loss. As coral reef environmental quality is reduced, we are likely to see greater impacts on recruits and a resultant loss of the smallest size classes of coral colonies in a population (Bak \& Meesters 1999). Such an event would exacerbate subsequent detrimental effects by limiting the recovery of the population in the future, particularly if recruitment is limited.

The roles of global environmental change and local anthropogenic effects in coral disease distributions remain unclear. However, this and other studies provide mounting evidence that environmental drivers, including temperature and sedimentation, and coral community characteristics (e.g. locally dominant species) may both impact coral diseases and reef health. Identification of factors influencing coral diseases and coral degradation is important for understanding the decline of coral reefs worldwide and developing viable strategies for the management of this important resource.

Acknowledgements. We gratefully acknowledge A. L. Ford, K. E. Marsh, T. B. Thyberg, and the staff at the Perry Institute for Marine Science for invaluable field assistance on this project. We thank 3 anonymous reviewers whose comments helped improve this manuscript. This research was supported by grants to J.D.V. and L.L.R. from the National Oceanic and Atmospheric Administration's Caribbean Marine Research Center (Projects CMRC-02-PRJV-01-02A, CMRC-03-PRJV01-03C) Undersea Research Program, an EPA STAR Fellowship (U-91608601-0) to J.D.V., and partial funding from the National Institutes of Health (NIH/NIGMSS06GM8205) to L.L.R. This is contribution 91 from the Tropical Biology Program at Florida International University. Views expressed herein are those of the authors and do not necessarily reflect the views of CMRC, NOAA, or any of their sub-agencies.

\section{LITERATURE CITED}

Alker A, Smith G, Kim K (2001) Characterization of Aspergillus sydowii (Thom et Church), a fungal pathogen of Caribbean sea fan corals. Hydrobiologia 460:105-111

Antonius A (1973) New observations on destruction in reefs. Abs Assoc Isl Mar Lab Caribb 10:3 
Bak RPM, Meesters EH (1999) Population structure as a response of coral communities to global change. Am Zool 39:56-65

Banin E, Ben-Haim Y, Fine M, Israely T, Rosenberg E (2002) Virulence mechanisms of the coral bleaching pathogen Vibrio shiloi. Proc 9th Int Coral Reef Symp 2:1261-1266

Borger J (2003) Three scleractinian coral diseases in Dominica, West Indies: distribution, infection patterns, and contribution to coral tissue mortality. Rev Biol Trop 51(Suppl 4):25-38

Brown LE (1997) Coral bleaching: causes and consequences. Proc 8th Int Coral Reef Symp 1:65-74

Bruckner AW, Brucker RJ (1997) The persistence of black band disease in Jamaica: impact on community structure. Proc 8th Int Coral Reef Symp 1:65-74

Bruckner AW, Bruckner R, Williams E Jr (1997) Spread of a black band disease epizootic through the reef system in St. Ann's Bay, Jamaica. Bull Mar Sci 61:919-928

Cervino J, Goreau T, Nagelkerken I, Smith G, Hayes R (2001) Yellow band and dark spot syndromes in Caribbean corals: distribution, rate of spread, cytology, and effects in abundance and division rate of zooxanthellae. Hydrobiologia 460:53-63

Dennis GD, Wicklund RI (1993) The relationship between environmental factors and coral bleaching at Lee Stocking Island, Bahamas in 1990. In Ginsburg RN (compiler) Proc Colloq on Global Aspects of Coral Reefs: health, hazards and history. University of Miami, Miami, FL, p 167-173

Dustan P (1977) Vitality of reef coral populations off Key Largo, Florida: Recruitment and mortality. Environ Geol 2:51-58

Edmunds P (1991) Extent and effect of black band disease on Caribbean reefs. Coral Reefs 10:161-165

Fitt WK, Brown BE, Warner ME, Dunne RP (2001) Coral bleaching: interpretation of thermal tolerance limits and thermal thresholds in tropical corals. Coral Reefs 20:51-65

Garzon-Ferreira J, Gil D (1998) Another unknown Caribbean coral phenomenon? Reef Encounters 24:10

Gil-Agudelo D, Garzon-Ferreira J (2001) Spatial and seasonal variation of dark spots disease in coral communities of the Santa Marta area (Columbian Caribbean). Bull Mar Sci 69:619-629

Gilmour J (1999) Experimental investigation into the effects of suspended sediment on fertilization, larval survival and settlement in a scleractinian coral. Mar Biol 135:451-462

Gladfelter WB, Gladfelter EH, Monahan RK, Ogden JC, Dill RF (1977) Environmental studies of Buck Island Reef NM, St. Croix, US Virgin Islands. US Dept Interior, National Park Service Report, Washington, DC

Goreau TJ, Cervino J, Goreau M, Hayes R and 13 others (1998) Rapid spread of diseases on Caribbean coral reefs. Rev Biol Trop 46:157-172

Green EP, Bruckner AW (2000) The significance of coral disease epizootiology for coral reef conservation. Biol Conserv 96:347-361

Harvell CD, Kim K, Burkholder JM, Colwell RP and 9 others (1999) Emerging marine diseases: climate links and anthropogenic factors. Science 285:1505-1510

Submitted: September 15, 2004; Accepted: May 27, 2005
Kaczmarsky L, Draud M, Williams E (2005) Is there a relationship between proximity to sewage effluent and the prevalence of coral disease? Caribb J Sci 41:124-137

Kim K, Harvell CD (2002) Aspergillosis of sea fan corals: dynamics in the Florida Keys. In: Porter JW, Porter KG (eds) The Everglades, Florida Bay, and coral reefs of the Florida Keys: an ecosystem sourcebook. CRC Press, Boca Raton, FL, p 813-824

Kuta KG, Richardson LL (1996) Abundance and distribution of black band disease on coral reefs in the northern Florida Keys. Coral Reefs 15:219-223

Kuta KG, Richardson LL (2002) Ecological aspects of black band disease of corals: relationships between disease incidence and environmental factors. Coral Reefs 21:393-398

Nugues M (2002) Impact of a coral disease outbreak on coral communities in St. Lucia: what and how much has been lost? Mar Ecol Prog Ser 229:61-71

Porter JW, Lewis SK, Porter KG (1999) The effect of multiple stressors on the Florida Keys coral reef ecosystem: a landscape hypothesis and physiological test. Limnol Oceanogr 44:941-949

Porter J, Dustan P, Japp W, Patterson K, Kosmynin V, Meier O, Patterson M, Parsons M (2001) Patterns of spread of coral diseases in the Florida Keys. Hydrobiologia 460:1-24

Remily ER (2004) Ecological physiology of Aurantimonas coralicida: pathogen of the coral disease white plague type II. MS thesis, Florida International University, Miami

Richardson LL (1997) Occurrence of the black band disease cyanobacterium on healthy corals of the Florida Keys. Bull Mar Sci 61:485-490

Richardson LL (1998) Coral diseases: what is really known? Trends Ecol Evol 13:438-443

Richardson LL, Kuta KG (2003) Ecological physiology of the black band disease cyanobacterium Phormidium corallyticum. FEMS Microbiol Ecol 43:287-298

Richardson LL, Goldberg W, Kuta KG, Aronson RB and 5 others (1998) Florida's mystery coral killer identified. Nature 392:557-558

Riegl B, Branch GM (1995) Effects of sediment on the energy budgets of four scleractinian (Bourne 1900) and five alcyonacean (Lamouroux 1816) corals. J Exp Mar Biol Ecol 186(2):259-275

Rosenberg E, Ben-Haim Y (2002) Microbial diseases of corals and global warming. Environ Microbiol 4:318-326

Rosenberg E, Loya Y (2004) Coral health and disease. Springer, Berlin

Rützler K, Santavy D, Antonius A (1983) The black band disease of Atlantic reef corals. III. Distribution, ecology and development. PSZN I: Mar Ecol 4:329-358

Sutherland KP, Porter JW, Torres C (2004) Disease and immunity in Caribbean and Indo-Pacific zooxanthellate corals. Mar Ecol Prog Ser 266:273-302

Weil E (2004) Coral diseases in the wider Caribbean. In: Rosenberg E, Loya Y (eds) Coral health and disease. Springer, Berlin, p 35-68

Weil E, Urreiztieta I, Garzon-Ferreira J (2002) Geographic variability in the incidence of coral and octocoral diseases in the wider Caribbean. Proc 9th Int Coral Reef Symp 2:1231-1238

Proofs received from author(s): December 15, 2005 